\title{
Digital Flipbook Empowerment as A Development Means for History Learning Media
}

\author{
Muhammad Abror A, Nunuk Suryani, Deny Tri Ardianto \\ Faculty of Teacher Training and Education of Universitas Sebelas Maret, Indonesia \\ e-mail: abror.m@student.uns.ac.id, nunuksuryani@staff.uns.ac.id,denytri@staff.uns.ac.id
}

\begin{abstract}
The purpose of this research was to help empower the atmosphere and climate of learning students who had different learning styles with the prior generation by using a digital-based instructional media such as digital flipbook. The research methods used were Research and Development, the ADDIE model. Data collection obtained through interviews, questionnaires, or questionnaires with direct observation. The data analysis technique used was an Independent sample test of hypothesis testing via SPSS version 26. The objects of the research were $11^{\text {th }}$-grade students of Public High School 1 Dagangan, academic year 2019/2020. The results of the research development of digital flipbook learning media on the effectiveness test stage through post-test of the control class and the experimental class showed the mean difference or the average grade of the experimental class (XI Social Sciences 2) 91.6 and grade control (XI Social Sciences 1) 83.5. Thus, digital flipbook learning media that have been developed have succeeded in gaining a significant increase in students' grades as well as succeeding as delivering information media to students in the classroom.
\end{abstract}

Keywords: Digital Flipbook; History Learning

\section{Introduction}

The development of science and technology encourages means to excogitate a more qualified and knowledgeable generation of human beings, which one of them is by improving the quality of education (Kaiful, 2013), such as the digital technology development in the industrial revolution 4.0 era. Digital technology development in the industrial revolution 4.0 era has now brought changes and influenced various aspects of human life, including in the field of education (Putrawangsa \& Hasanah, 2018). Adoption and adaptation of technology have led to the paradigm of doing new things in a new way in the changing process of learning paradigm, giving impacts to various aspects of learning, including instructional design and media development that need to be integrated with technological developments (Mawarni \& Muhtadi, 2017). On that account, this integration results in a variety of technology-based products that are eminent in visuals and benefits for learning.

The development of science and technology towards the learning process spurred the development of learning resources and learning media, one of which computers are used as tools of learning media (Information and Communication Technology) or ICT, ICT facilities become a benchmark of a country's education quality (Mulyaningsih \& Saraswati, 2017). Learning media is one of the learning systems that is used as a means of delivering messages and educative information between educators and students and can build effective and efficient learning (Wahyuliani et al., 2016). Learning media can be categorized into traditional media and digital media. Traditional media in this context is media that is used without the support of computer use when, on the other hand, digital media surely must be supported by computer use (N. Suryani, 2016b). The use of traditional media or digital media certainly adapts to the needs and targets of students' concept mastery, and also adjusts to the development of science today. For an example of the development of information and communication technology, schools around the world integrate their learning process with educational media and e-learning projects, in Hong Kong, some schools integrate information technology in educational media, school students use laptops and iPads (smartphones) to support the learning process as well as exploring the learning process itself (Lee, 2016).

The development of digital learning media has not been much developed in the subjects of history. Historical learning does not always use conventional methods, but it requires a learning method that is more modern and follows the needs of the development and 
advancement of information and communication technology for learning purposes. The use of digital flipbooks is a smart and innovative solution in learning history (Putra, 2016). Various materials related to history will be more concrete and easily understood if being delivered by teachers with the support of pictures, photos, documentaries or animation of spaces in the Egyptian pyramid and as visualization are means that can be done to concretize something abstract (N Suryani, 2016a). Surveys prove that teachers who use digital information sources reveal various reasons that the use of digital information sources facilitates eases and saves time in delivering the study, integrate key sources in learning, improves student learning interest and allows the learning process to do new things in the classroom (Rafiq \& Ameen, 2012). The use of technology as a learning media has been initiated by the government as one of the tools of education to obtain information knowledge, one of which is seen is the replacement of conventional student handbooks into digital books or electronic books or ebooks (Ghofur, 2015).

The idea of the flipbook was originally only used to display animation, and now it is adopted by many vendors for various types of digital applications, such as magazines, books, comics, and others. Digital book display design that is now in great demand by the public, which are digital books with a three-dimensional e-book technology known as flipbooks, this page can be opened like reading a book on a monitor (Hardiansyah, 2016). Flipbook is a classic animation created by a piece of paper, such as a thick book, and each paper aimed at describing something that seems to make things move as the process is opened (Nafi et al., 2018). The presence of digital books (digital flipbooks) occurs because they cannot be separated from technological and information advancements through the features contained in digital bookmaking applications. Moreover, amid the current 4.0 industrial revolution, books have undergone a change from print to digital form, so that they are operationally more practical and can maintain the quality of books, so they are not worn out by time (Divayana Bina Marga, Suyasa PWA, 2019).

Flipbooks are different from textbooks or regular books. Textbooks have weaknesses in appearance, manufacturing processes, and their use. Ordinary books or printed books are easily damaged and torn, and their use in learning is less interesting, whereas flipbooks are in the form of interactive electronic formats by combining elements of text, pictures, videos so that the learning process can be attractive for students (Diani \& Hartati, 2018). Flipbook helps someone or students make words and images more positive in their mind. It is very effective for gaining knowledge and making the learning process easier (Jain, 2017). It provides indepth knowledge of the topic interestingly and effectively for people or students. A digital flipbook or flipbook maker can integrate sound shows, graphics, images, animations, and movies so that the information presented is richer compared to popular books (Safitri, 2017). Some other advantages are, it can import files with various options: import pdf files to turn them into flip pages, import images (JPG, BMP, Jpeg, Png, Gif), import movies and videos (Swf, Flv, F4v, Mp4), add background music to the flipbook.

Research on digital flipbooks has been widely carried out in the field, for example, research from Bagus (2016), with research results proving that student learning outcomes can be seen from the results of the pretest and posttest. The average result of the experimental class pretest was 75.88, and the average result of the control class pretest was 75.58. Then the experimental class was given treatment through innovation flipbook learning media. After being given treatment, the average result of the experimental class posttest was 81.61. Moreover, the average result of the control class posttest that was not given treatment was 77.05. T-test results at posttest class XI RPL 1 and 2 showed a T-value of 2.28 and a P-Value of 0.026 , which was smaller than the critical limit of 0.05 . The t-count value was 2.28 , and Ttable value 1.6627 showed that the value of $\mathrm{t}$-count was greater than $\mathrm{t}$-table, then $\mathrm{H} 1$, which mentions the differences in the use of learning media in the form of innovation and learning using conventional media is accepted.

Also, research from Hayati, Budi, \& Handoko (2015) shows the results of the development of Flipbook are the results of media experts, namely $91.46 \%$ of the material experts $94.17 \%$ and the results of experiments on users obtained $99.38 \%$ of educators and $96.70 \%$ of students. The average percentage of all aspects increased by $57.23 \%$. It can be 
concluded that overall multimedia-based physics flipbooks can improve high school student learning outcomes. Other research is from Divayad (2019), which shows that the results of research on Digital Book Content Design for Evaluation Course Evaluation by Adopting the Superitem Concept Based on Kvisof Flipbook Maker in Industrial Era 4.0 fall into the good category (Series, 2019).

Digital flipbooks making through Kvisoft Flipbook Maker or the latest development results, Flip Pdf Professional, which is a software to make the display of books or teaching materials into a digital electronic book or Flipbook, the software can be accessed on the Internet (Pusparini, 2016). Moreover, it can adjust the display output template, turn the book interesting, control style buttons are customizable, adjust the back color and images, adjust the paper book style, close the page and page settings, font settings, and text pages. Also, the flexible output format outputs into "exe" format, publishing it as HTML, which makes it possible to upload to websites to be viewed online, sending quick emails to share widely in the form of ZIP (S. Suryani, 2018).

\section{Methods}

The research method used was the Research and Development of the ADDIE model. ADDIE is a product development concept that has the acronym to Analyze, Design, Development, Implementation, and Evaluation (Branch, 2009). The ADDIE concept is applied here to build performance-based learning. The educational philosophy for the ADDIE application is that intentional learning must be student-centered, innovative, authentic, and inspirational.

Development with ADDIE contains several stages that can be used to design and develop effective and efficient training or learning programs (Benny, 2014). At this stage, the author focused on the analysis phase of media needs, product design, and development. The material used by the author in research analysis of the need to use digital flipbook learning media in history learning was Soekarno's Internationalism in the 1945 BPUPKI session.

This research was conducted at Public High School 1 Dagangan, Madiun, with the subjects of the research, was the $11^{\text {th }}$-grade students of Natural Sciences and Social Sciences, first semester 2019/2020. Data collection techniques in this research used literature study, interviews, and direct observation in the classroom and questionnaires. The questionnaire included an attitude questionnaire and questionnaire for learning media needs and teacher interview questionnaire.

The first technique used in this research was the study of literature or literature used in supporting research and development of learning media as research support material. The author collected information and theories related to this appropriate developmental research. Information and research theory was used as supporting material on the background of the problem, discussion, and problems in the research development of digital flipbook learning media. The theory and information came from books, national and international journals, and other scientific articles.

The second technique was the interview. An interview or can be announced by a field studio that uses interview guidelines to the target informant. The interview method used people to use that for a particular purpose or task by trying to talk or converse face to face with that person's informant (Koentjaraningrat, 1991). Interviews consisted of two types, namely structured interviews and unstructured interviews. Structured interviews that are used when researchers or data collectors have been obtained with certainty about what information obtained through unstructured interviews researchers do not use interview guidelines that have been arranged in a systematic and complete data (Sugiyono, 2005). This study used structured interviews because it was composed of systematic and complete author questions for the teacher for the needs of instructional media in learning in the classroom. While observations and discussions on methods and techniques with direct and ongoing observations and participation were held (Sukmadinata, 2012). The author saw and participated directly to check the student learning process in the classroom.

The third technique was questionnaire distribution. The purpose of distributing questionnaires was to collect research data regarding the analysis of learning media 
development needs. The questionnaire is a data collection technique that is done by giving several questions or statements to be answered by research respondents (Sugiyono, 2015).

Data analysis used to obtain this difference in value should pass normality test, homogeneity test, and, finally, the difference in value test or sample mean that had been obtained through the control class and experimental classes through parametric statistical tests. Furthermore, the data analysis technique in this study used the SPSS version 26 software application using the value difference test obtained by the independent sample test from the experimental class (the class treated by learning media) and the control class (the class not treated with learning media). Independent test samples on this stage would be tested using the hypothesis $\mathrm{HO}$ and $\mathrm{HI}$, whether $\mathrm{HO}$ was accepted or vice versa $\mathrm{HI}$ was rejected.

\section{Results and Discussion}

Based on an analysis of the needs of digital flipbook learning media in Public High School 1 Dagangan during the history learning in the classroom is teachers rarely use learning tools media in presenting historical material, teachers tend to teach conventionally. The conventional way of teaching here is that history teachers tend to use the lecture method and the commonly used PowerPoint learning tool media, often teachers only use the lecture method in conveying history learning in class. This was expressed directly by students when the researcher conducted an initial analysis in school. Thus, students need learning tool media to support the understanding of historical material taught in class. This digital flipbook learning media is becoming something new as a supporting learning media in student learning in class.

Table 1. Analysis of Learning Barriers and Alternative Solutions

\begin{tabular}{ll}
\hline \multicolumn{1}{c}{ Learning Barriers } & \multicolumn{1}{c}{ Alternative Solutions } \\
\hline $\begin{array}{l}\text { Teachers have never used flipbook } \\
\text { learning media }\end{array}$ & $\begin{array}{l}\text { Penulis mengenalkan media pembelajaran flipbook } \\
\text { kepada guru dan menjelaskan tata cara penggunaannya }\end{array}$ \\
\hline $\begin{array}{l}\text { History learning rarely uses learning } \\
\text { media }\end{array}$ & $\begin{array}{l}\text { Penambahan media pembelajaran flipbook digital pada } \\
\text { mata pelajaran sejarah agar membantu proses belajar } \\
\text { siswa }\end{array}$ \\
\hline $\begin{array}{l}\text { Students' historical material } \\
\text { understanding so far has been lacking } \\
\text { due to limited learning support such history subjects, it is expected to be able to support } \\
\text { as learning media. }\end{array}$ & $\begin{array}{l}\text { hidents 'understanding of historical material because it } \\
\text { is designed to attract students' interest in learning } \\
\text { history. }\end{array}$ \\
\hline
\end{tabular}

A conclusion that can be drawn from the problems or obstacles in learning history in schools is generally the lack of integration of digital information technology into learning history. Besides, teachers are preoccupied with making learning details as well as matters concerning administrative office needs related to teaching reports. Generally, teachers are not too literate about digital technology because of the age factor and understanding of digital technology that is considered complicated to learn because they do not understand the steps and procedures for using digital technology. 
Table 2. Learning Tools and Other Supporting Devices Needed

\begin{tabular}{ll}
\hline \multicolumn{1}{c}{ Learning Tools Needed } & \multicolumn{1}{c}{ Learning Tools and Learning Support } \\
\hline Software & $\begin{array}{l}\text { Digital Flipbook application or Flip Pdf Builder, Microsoft Word, } \\
\text { Microsoft PowerPoint, }\end{array}$ \\
\hline Hardware & Smartphone, Laptop, Notebook or Computer, LCD Projector, \\
\hline Learning Media & $\begin{array}{l}\text { Learning Implementation Plan (RPP), Syllabus, Historical Learning } \\
\text { Material regarding the 1945 BPUPKI, Satisfaction Questioner of } \\
\text { the Use of Digital Flipbook Learning Media, Questionnaire for } \\
\text { Digital Flipbook Learning Media Needs. }\end{array}$ \\
\hline
\end{tabular}

Based on the results of the table above, it can be observed that there are several learning tools and learning support devices that must be prepared to smooth the process of applying digital flipbook learning media to make the process of applying digital flipbook learning media can run smoothly. They are also needed to guarantee the accordance with the learning design and learning concepts that have been prepared early. Besides, coordination with class teachers and students have to run well so that the process of implementing and developing media in Public High School 1 Dagangan can be as expected. So, the results of research into the development of digital flipbook learning media are successful and can be one of the references in learning media in schools and alternative use of learning media, so that the atmosphere and appearance of learning can be more exciting and passionate in the classroom.

Under the results of the analysis of learning media needs in the early stages of media needs in learning. The author designs the media to be in line with the students' needs in learning. From the results of the analysis, students need educational information delivery media to support the learning process in the classroom. On this account, the author took the initiative to develop digital-based learning media, namely digital flipbook learning media. Through these media, students are expected to be able to help the teaching and learning process in the classroom.

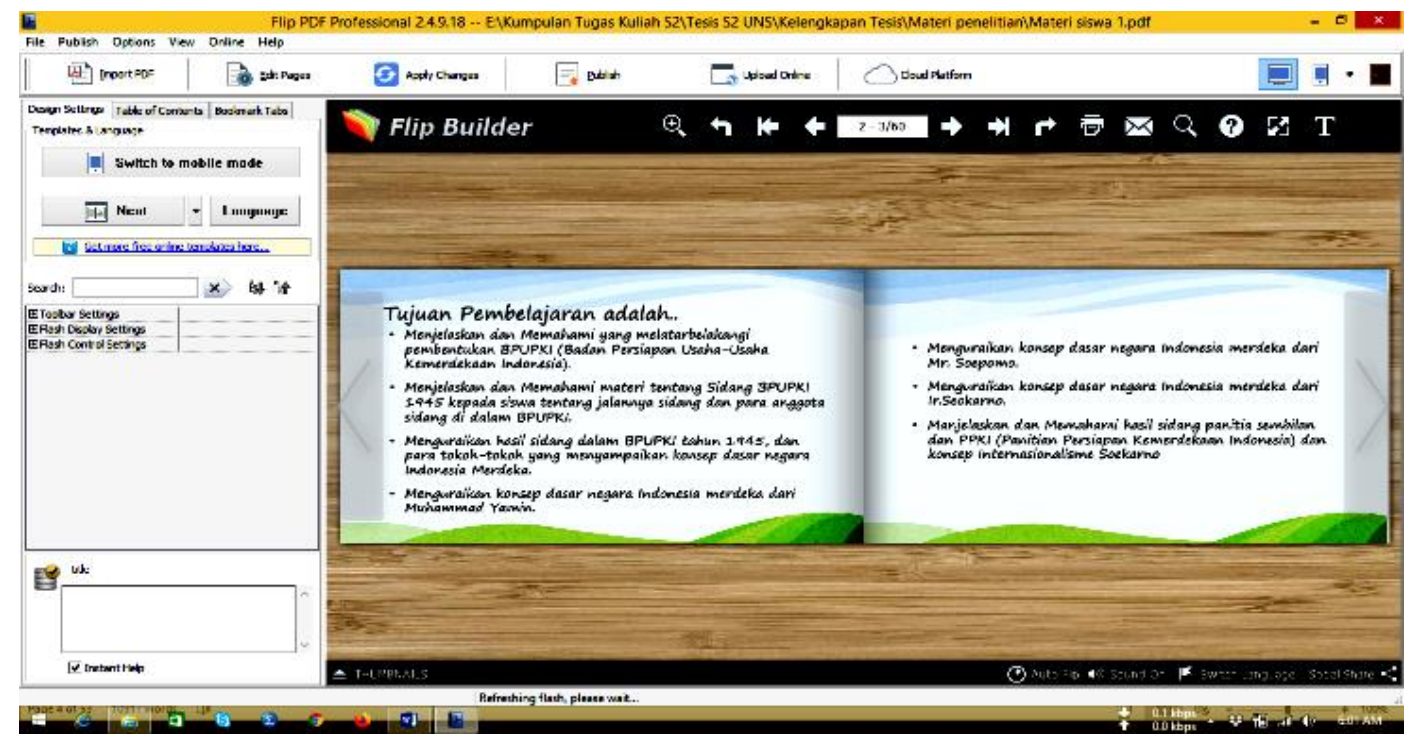

Figure 1. Initial Design of Digital Flipbook Learning Media

After going through the media needs analysis phase and the initial design stage of learning media intended for $11^{\text {th }}$-grade students of Natural Sciences and Social Sciences. Then the next stage is the development of digital flipbook learning media. In the development of instructional media, there are stages of assessment of the validation of media experts and material experts, each of which is validated by two media experts and material experts. Then to calculate the resulting formula from material validation and media validation. 
Table 3. Rating Scores of Media Experts and Material Experts

\begin{tabular}{cc}
\hline Category & Validation Score \\
\hline Very Good (VG) & 5 \\
\hline Good (G) & 4 \\
\hline Enough (E) & 3 \\
\hline Deficient (D) & 2 \\
\hline Very Deficient (VD) & 1 \\
\hline
\end{tabular}

(Sugiyono, 2015)

Table. 4. Media Feasibility Score Table and Learning Materials

\begin{tabular}{cc}
\hline Score Interval & Rating Score \\
\hline $0 \%-20 \%$ & $20 \%$ \\
\hline $21 \%-40 \%$ & $40 \%$ \\
\hline $41 \%-60 \%$ & $60 \%$ \\
\hline $61 \%-80 \%$ & $80 \%$ \\
\hline $81 \%-100 \%$ & $100 \%$ \\
\hline
\end{tabular}

Scores Information:

(Riduan, 2012)

$20 \%=$ Very Inadequate

$40 \%=$ Not Eligible

$60=$ Enough

$80 \%$ = Adequate

$100 \%=$ Decent

\section{HASIL VALIDASI AHLI MEDIA DAN MATERI}

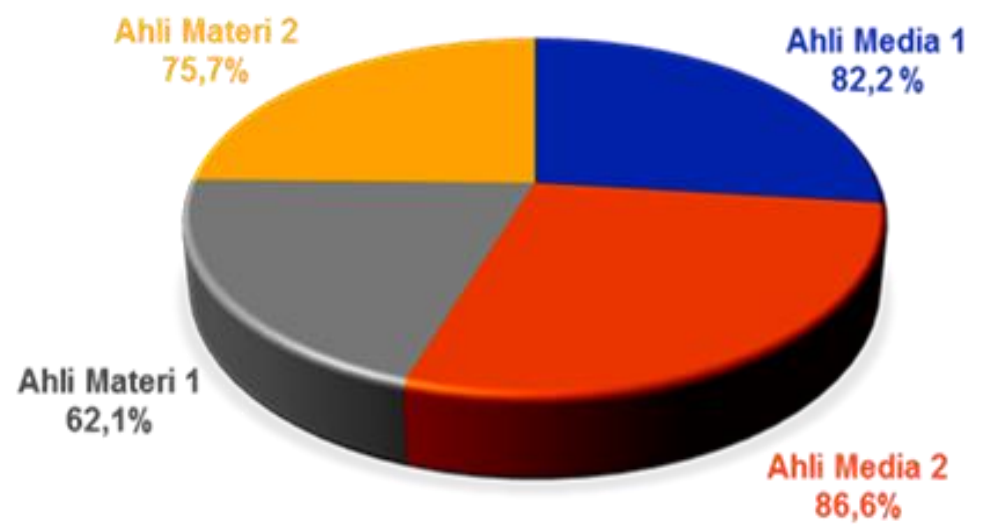

Figure 2. Chart of results of Digital Flipbook Learning Media Validation and Learning Materials in Learning Media Development.

After conducting media validation through two media experts, namely media expert one and media expert two, as well as material expert one and material expert two the researcher revised and improved the media and material in the development of instructional media according to the suggestions and input of media experts and material experts. It is needed before learning media and material are implemented or applied and tested at the evaluation stage or the test stage of the effectiveness of digital flipbook learning media. 

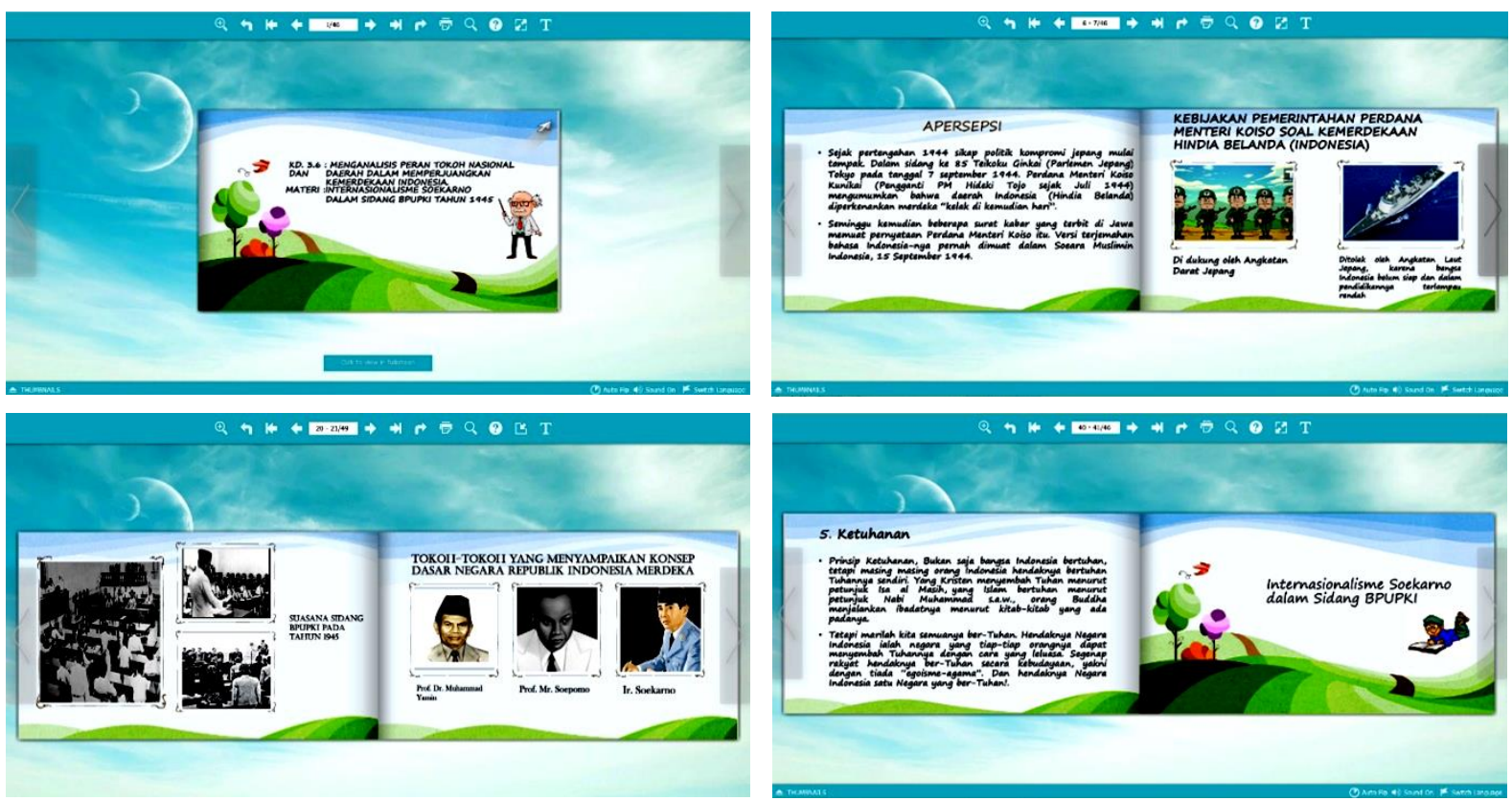

Figure 3. Design Revision and Final Results of Digital Flipbook Learning Media.

After the stages of developing digital flipbook learning media and revising and improving digital flipbook learning media, the next step is testing the implementation of digital flipbook learning media. This test is conducted to determine the effectiveness of the media to be applied to the effectiveness test of digital flipbook learning media. Experiment development on small group studies conducted the application of digital flipbook learning media to students with ten students as the objects who used digital flipbook learning media. The results achieved from these ten students as the objects revealed that they were interested and agreed to learn historical material using digital flipbook learning media. Then for a large group experiment conducted by the author, the application of digital flipbook learning media to 25 students as the objects revealed that they were also interested and agreed to learn historical material using digital flipbook learning media. Some reasons students are interested and agree to use digital flipbook learning media are, the delivery of historical material is equipped with interesting visual and audiovisual aspects with various color gradations, making it easier and interesting for students to understand and listen to historical material.

Small group experiments and large group experiments have resulted in a positive impact and are also positively welcomed by students with digital flipbook learning media. Presentation of the material with the addition of videos makes students more impressed in learning history as well as paying close attention to historical videos presented in digital flipbook learning media. By this, the use of digital flipbook learning media for history learning is highly recommended for teachers to teach in the classroom. The use of digital flipbook learning media can help the delivery of historical material in a more interesting, innovative, and creative way. Thus, the use of flipbook learning media is very feasible to use in learning in the classroom both in learning history and in other learning in the classroom.

The use of learning media in schools began to campaign under the process of transformation of communication and information technology in the past few decades. One of the reasons is that media helps the work of teachers as educators in teaching in the classroom, and the students wish to have a pleasant learning climate as well for their learning passion. Through the use of media, it is expected that the potential use of the students' senses can be optimally accommodated so that the learning outcomes of students increase, one trait of media characteristics is it can improve learning outcomes by providing a combination of elements of text, images, animations, and multimedia presentations can be accommodated in one the media (Chaidar, 2014). 
The use of flipbook learning media is motivated by the congruence factor of students' characteristics, which are more interested in the use of media as a learning tool in the classroom, the congruence of learning styles, the congruence of the material in learning (Roro et al., 2019). The use of learning media in the teaching and learning process can increase desires and interests as well as learning stimulation and even affect the psychological condition of the students. Learning media also help students at the learning orientation stage to become more effective and efficient in delivering learning content (Anshori, 2017).

The use of media can make learning effective by using media, and it can also simplify problems, especially in conveying things that are new and extraneous to students. The successful use of media could not be separated from how the media was planned and wellchosen. Media that can change student behavior and improve student learning outcomes were not invented spontaneously, but a comprehensive analysis is needed by paying attention to various aspects that could influence the success of learning (Utami, 2017). One goal of the uses of learning media is, it is expected to create an exciting and conducive learning atmosphere is the use of multimedia flipbooks using the learning media is expected to provide renewal in the learning process in class and increase student achievement (Sugianto et al., 2017).

The research results of the analysis of the developing digital flipbook learning media from the use of digital flipbook learning media at the effectiveness test stage through the posttest of the control class and experimental class showing the mean difference or the average value of the experimental class (XI Social Sciences 2) 91.6 and the control class (XI Social Sciences 1) 83.5. As the decision making is the significance value (2-tailed) of 0,000 is smaller than $0.05(0,000<0.05)$, thus the average acquisition value of the experimental class and control class students is not the same or experiences a significant difference between the two classes. Hence, the mean values of the two classes are not the same ( $\mathrm{H} 1$ rejected). As a result of that, the effectiveness test that has been done by the author has succeeded in achieving the expected value. It also has met or achieved the research objectives. It can be seen that the acquisition value of the experimental class (treated or tested) is greater than the value obtained by the control class (not treated or tested). Besides, the development of digital learning media flipbook results from the experimental class and control class show different values which are significant and can help and support the learning process of students in the classroom. On this account, the development of digital flipbook learning media has succeeded in gaining a significant increase in grades for students as well as being successful as a medium for delivering educational information to students in the classroom.

Thus, the use of digital flipbook learning media can help students' learning activities in the classroom with a significant increase in grades in the experimental class (classes that are taught with digital flipbook learning media). So that the use of digital flipbook learning media can be maximally utilized by the teacher to support the teaching and learning process in the classroom and help students understand the subject matter in the classroom.

\section{Conclusion}

The development of digital flipbook learning media can help teachers empower history lessons to achieve an understanding of historical material in the classroom. Learning history in the classroom requires innovation and creation in the delivery of teaching and learning. Conventional learning is felt less supportive of the current generation. Therefore, digital-based learning is needed to help students become more active in learning and achieving academic achievements in school. One alternative solution is to use a digital flipbook as a learning media in the classroom. Visual and audiovisual presentations with color gradations and historical video presentations help students provide a more passionate learning experience as well as innovative and creative learning references and do not miss the historical material that is presented, which carries a lot of deep moral values. In its practice of developing digital flipbook learning media, it gets a good response from students in small group experiments as well as in the large group experiments and produces useful products on the product effectiveness test. Thus, this digital flipbook learning media becomes a smart solution and alternative 
solutions as a digital learning media amid the rapid development of technology and information in the field of education.

Therefore, it is highly recommended and very feasible to use digital flipbook learning media used and applied in $11^{\text {th }}$-grade students of Public High School 1 Dagangan to assist the process of teaching and learning activities in the classroom. In the next research, the researcher and teacher are expected to be able to collaborate again to improve further the results of the research. With this, further research can produce better research and significantly increase from the results of research that have been obtained. Furthermore, there are new learning media innovations for the development of student learning at school and the academic development of students in the class so that students can have a more engaging, creative, and innovative learning experience with other digital-based learning media. At last, students can achieve academic achievement in the classroom with brilliant and proud of themselves, parents, and their school.

\section{References}

Anshori, S. (2017). Pemanfaatan Tik Sebagai Sumber Dan Media Pembelajaran. Jurnal IImu Pendidikan PKn Dan Sosial Budaya, 9924(9878), 10-20.

Bagus, R. (2016). Penerapan Inovasi Flipbook Sebagai Media Pembelajaran Untuk Meningkatkan Hasil Belajar Pengenalan PHP Kelas XI RPL di SMK Negeri 2 Mojokerto. It-Edu, 1(02), 42-48.

Benny, P. (2014). Desain dan Pengembangan Program Pelatihan Berbasis Kompetensi: Implementasi Model ADDIE. Prenada Media Group.

Branch. (2009). Instructional Design: The ADDIE Approach. Springer Science Business Media.

Chaidar, H. (2014). Pemanfaatan Teknologi Informasi dan Komunikasi dalam Pembelajaran di SMA Muhammadiyah Tarakan. Jurnal Kebijakan Dan Pengembangan Pendidikan, 2(2), 184-192.

Diani, R., \& Hartati, N. S. C. A. (2018). Flipbook berbasis literasi Islam : Pengembangan media pembelajaran fisika dengan 3D pageflip professional. Jurnal Inovasi Pendidikan IPA, 4(2), 234-244. https://doi.org/10.21831/jipi.v4i2.20819

Divayana Bina Marga, Suyasa PWA, A. I. (2019). Desain Digital Book Konten untuk Penilaian dan Evaluasi Program oleh Mengadopsi Superitem Konsep Berdasarkan Kvisoft Flipbook pembuat di era Industri 4 . 0 Desain Digital Book Konten untuk Penilaian dan Evaluasi Program oleh Mengadopsi Superitem Konsep Be. Journal of Physics, 0-6.

Ghofur, A. \& R. K. (2015). PENGEMBANGAN e-BOOK BERBASIS FLASH KVisoft FlipBook PADA MATERI KINEMATIKA GERAK LURUS SEBAGAI SARANA BELAJAR SISWA SMA KELAS X. Jurnal Inovasi Pendidikan Fisika (JIPF), 04(2), 176-180. https://doi.org/10.13075/ijomeh.1896.00471

Hardiansyah, D. (2016). Pengembangan Media Flash Flipbook dalam Pembelajaran Perakitan Komputer untuk Meningkatkan Hasil Belajar Siswa Kelas X TKJ SMK Negeri 7 Surabaya. It-Edu, 1(02).

Hayati, S., Budi, A. S., \& Handoko, E. (2015). Pengembangan Media Pembelajaran Flipbook Fisika untuk Meningkatkan Hasil Belajar Peserta Didik. Prosiding Seminar Nasional Fisika (e-Jurnal) SNF2015, IV, 49-54.

Jain, S. (2017). Development and Field-Testing of A Flipbook on 'Vegetables in Diet ' for Rural Women. Journal of Community Mobilization and Sustainable Development, Vol. 12(1)(January-June), 136-140.

Kaiful, U. (2013). Penerapan media digital dalam pembelajaran apresiasi batik kelas $x$ SMA negeri 1 Blega. Jurnal Pendidikan Seni Rupa, 1(1), 100-105.

Koentjaraningrat. (1991). Metode - Metode Penelitian Masyarakat. Gramedia Pustaka Utama.

Lee, A. Y. L. (2016). Media education in the School 2.0 era: Teaching media literacy through laptop computers and iPads. Global Media and China, 1(4), 435-449. https://doi.org/10.1177/2059436416667129 
Mawarni, S., \& Muhtadi, A. (2017). Pengembangan digital book interaktif mata kuliah pengembangan multimedia pembelajaran interaktif untuk mahasiswa teknologi pendidikan. Jurnal Inovasi Teknologi Pendidikan, 4(1), 84. https://doi.org/10.21831/jitp.v4i1.10114

Mulyaningsih, N. N., \& Saraswati, D. L. (2017). Penerapan Media Pembelajaran Digital Book Dengan Kvisoft Flipbook Maker. JPF Jurnal Pendidikan Fisika, V(1), 25-32.

Nafi, U., Suprapta, B., \& Wijaya, D. N. (2018). MEMBANGUN MAHASISWA OTONOM BELAJAR. 320(ICKSE 2018), 82-86.

Pusparini, A. (2016). Pengembangan Media Modul Digital Pemrograman Web dengan Kvisoft Flipbook Maker di SMK Negeri 1 Surabaya. It-Edu, 1(02), 19-27.

Putra. (2016). THEORITICAL REVIEW : TEORI PERBEDAAN GENERASI. Among Makarti, 9(18), 123-134.

Putrawangsa, S., \& Hasanah, U. (2018). Integrasi Teknologi Digital Dalam Pembelajaran Di Era Industri 4.0. Jurnal Tatsqif, 16(1), 42-54. https://doi.org/10.20414/jtq.v16i1.203

Rafiq, M., \& Ameen, K. (2012). Use of digital media and demand for digitized contents in higher education sector of Pakistan. The International Information \& Library Review, 44(3), 116-122. https://doi.org/10.1016/j.iilr.2012.04.007.

Riduan. (2012). Skala Pengukuran Variabel-Variabel Penelitian. Alfabeta.

Roro, R., Alicia, A., Wardhani, K., \& Yuridka, F. (2019). Pengaruh Media Flipbook Kimia Terhadap Hasil Belajar Siswa Pada Materi Koloid. 2(November), 22-25.

Safitri, I. (2017). Pengembangan E-Module Dengan Pendekatan Pembelajaran Matematika Realistik Berbantuan Flipbook Maker Pada Materi Bangun Ruang Sisi Datar Kelas Viii Smp. Aksioma, 6(2), 1. https://doi.org/10.26877/aks.v6i2.1397

Series, C. (2019). The Design of Digital Book Content for Assessment and Evaluation Courses by Adopting Superitem Concept Based on Kvisoft Flipbook Maker in the era of Industry 4. 0 The Design of Digital Book Content for Assessment and Evaluation Courses by Adopting Superitem. :: Journal of Physics: Conf. Series, 0-6. https://doi.org/10.1088/1742-6596/1165/1/012020

Sugianto, D., Abdullah, A. G., Elvyanti, S., \& Muladi, Y. (2017). Modul Virtual: Multimedia Flipbook Dasar Teknik Digital. The innovation of Vocational Technology Education, 9(2), 101-116. https://doi.org/10.17509/invotec.v9i2.4860

Sugiyono. (2005). Memahami Penelitian Kualitatif. Alfabeta.

Sugiyono. (2015). Penelitian Pendidikan: Pendekatan Kuantitatif, Kualitatif, dan RnD. Alfabeta.

Sukmadinata, N. S. (2012). Metode Penelitian Pendidikan. Remaja Rosdakarya.

Suryani, N. (2016a). Pengembangan Media Pembelajaran Sejarah Berbasis It. Sejarah Dan Budaya: Jurnal Sejarah, Budaya, Dan Pengajarannya, 10(2), 186-196. https://doi.org/10.17977/um020v10i22016p186.

Suryani, N. (2016b). Utilization of Digital Media to Improve The Quality and Attractiveness of The Teaching of History Nunuk Suryani. The 2nd International Conference On Teacher Training and Education Sebelas Maret University, 2(1), 131-144.

Suryani, S. (2018). Media Pembelajaran Inovatif dan Pengembangannya. Remaja Rosdakarya.

Utami, R. P. (2017). Pentingnya Pengembangan Media Pembelajaran. 12, 62-81.

Wahyuliani, Y., Supriadi, U., \& Anwar, S. (2016). Efektivitas Penggunaan Media Pembelajaran Flip Book Terhadap Peningkatan Hasil Belajar Siswa Pada Mata Pelajaran Pai Dan Budi Pekerti Di Sma Negeri 4 Bandung. TARBAWY: Indonesian Journal of Islamic Education, 3(1), 22. https://doi.org/10.17509/t.v3i1.3457 